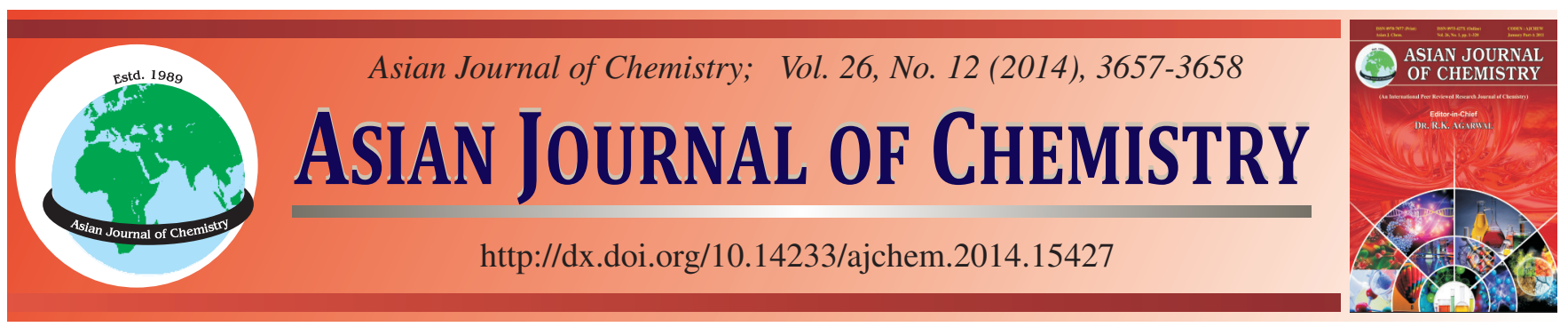

NOTE

\title{
Steroid Compounds from Sida szechuensis
}

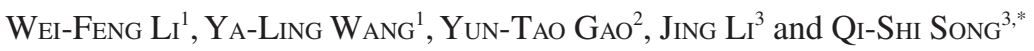

\author{
${ }^{1}$ Yunnan Vocational College of Tropical Crops, Puer, Yunnan, P.R. China \\ ${ }^{2}$ Yunnan University Nationalities, Key Lab Ethn Med Resource Chem, Kunming, P.R. China \\ ${ }^{3}$ Xishuangbanan Tropical Botanical Garden, Chinese Academy of Sciences, Kunming, Yunnan, P.R. China \\ *Corresponding author: Tel/Fax: +86 871 65138281; E-mail: songqs@xtbg.ac.cn
}

A new steroid compound, $2 \beta, 3 \beta, 14 \alpha, 20,21,22 \mathrm{R}, 24$-heptahydroxycholest-7-en-6-one (1), was isolated from Sida szechuensis. Its structure was determined by spectroscopic analysis, including extensive 1D and 2D-NMR data. Ten previously known compounds were also identified i.e., 3-O- $\beta$-D-glucopyranoside- $\alpha$-ecdysone, loliolide, 3- $O$ - $\beta$-D-galactopyranoside- $\beta$-ecdysone, 3 , 4,5,6-tetrahydro-3-methyl- $\beta$-carboline-5carboxylic acid, $\beta$-ecdysone, polypodine $\mathrm{B}, \alpha$-ecdysone, $\beta$-sitosterol, astragalin 6 "- $O$ - (4-hydroxycinnamoyl) and pterosterone. The antibacterial assay of the new compound showed that it has inhibitory effect on Escherichia coli with a concentration of $20 \mathrm{mg} / \mathrm{mL}$.

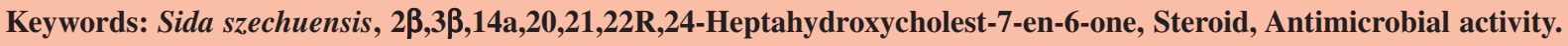

Sida szechuensis has been used as a folk medicine in China to treat problems like traumatic injury, enteritis and dysentery ${ }^{1}$. In previous papers, four sterols were reported e.g., $\alpha$-ecdysone, $\beta$-ecdysone, polypodine $\mathrm{A}$, polypodine $\mathrm{B}^{2,3}$. In order to find more bioactive compounds, the chemical components of Sida szechuensis were investigated. As a result, one new compound together with ten known compounds, $3-O-\beta$-D-glucopyranoside- $\alpha$-ecdysone (2), loliolide (3), 3- $O$ - $\beta$-D-galactopyranoside$\beta$-ecdysone (4), 3,4,5,6-tetrahydro-3-methyl- $\beta$-carboline-5carboxylic acid (5), $\beta$-ecdy-sone (6), poly- podine B (7), $\alpha$ ecdysone (8), $\beta$-sitosterol (9), astragalin 6"-O-(4-hydroxycinnamoyl) (10), pterosterone (11), were isolated from the ethyl acetate extract of this plant. Presence of compounds 1-4 in this plant is reported for the first time herein. In addition, compounds 1-11 were tested for their antibacterial activity using disk diffusion method ${ }^{4}$.

The above ground part of Sida szechuenisis were collected from Xishuangbanna, Yunnan, P.R. China. And a voucher specimen is kept at the laboratory of Research Group on Ethnomedicine, Xishuangbanna Tropical Botanical Garden Chinese Academy of Sciences.

Optical rotation was measured on a SEPA-3000 high sensitive polarimeter. IR $(\mathrm{KBr})$ spectra were measured on a Bio-Rad FTS-135 Spectrophotometer. NMR spectra were recorded on a Bruker DRX-500 instrument $(400$ or $500 \mathrm{MHz}$ for $\mathrm{H}^{1} \mathrm{NMR}$ and 100 or $125 \mathrm{MHz}$ for ${ }^{13} \mathrm{C} \mathrm{NMR}$ ), using TMS as an internal standard. FAB-MS spectra were recorded on VG
Auto Spec-3000 spectrometer. UV spectra were on Shimadzu Double-beam 210A Spectrophotometer. Precoated silica gel plates were used for TLC. Detection was one by spraying the plates with $10 \%$ sulfuric acid-ethanol, followed by heating.

Extraction and isolation: The air-dried above ground tissues of Sida szechuensis (18.5 kg) were extracted three times with $95 \%$ ethanol under room temperature, $24 \mathrm{~h}$ each time. The combined extract was concentrated and dissolved in $\mathrm{H}_{2} \mathrm{O}$ and then extracted with petroleum ether, ethyl acetate and $n$-butyl alcohol. The ethyl acetate extract was concentrated and applied to a silica gel column, eluting with $\mathrm{CHCl}_{3}-\mathrm{MeOH}$ $(1: 9 \rightarrow 9: 1)$, repeatedly to give $2 \beta, 3 \beta, 14 \alpha, 20,21,22 \mathrm{R}, 24-$ hepta-hydroxyl-cholest-7-en-6-one (1.074 g), together with other ten known compounds.

Characterization of compound (1): Colorless crystal; m.p. $244-246^{\circ} \mathrm{C} ;[\alpha]_{\mathrm{D}}^{20}+65.79^{\circ}\left(\mathrm{c} 0.76, \mathrm{CH}_{3} \mathrm{Cl}_{3}\right) ; \mathrm{UV}(\mathrm{MeOH})$ $\lambda_{\max }\left(\log _{\varepsilon}\right): 242 \mathrm{~nm}$; IR $\left(\mathrm{KBr}, v_{\max }, \mathrm{cm}^{-1}\right): 3375.26,3020.72$, 2964.24, 2948.17, 2876.96, 1644.51, 1463.02, 1379.03; HR-TOFMS $m / z$ : 496.3035 (Calcd. for $\mathrm{C}_{27} \mathrm{H}_{44} \mathrm{O}_{8}$ ); FAB-MS $\mathrm{m} / \mathrm{z}$ (rel. int.): $496[\mathrm{M}+1]^{+}$(100), 480 (30), 109 (6), 81 (13), 69 (16); ${ }^{1} \mathrm{H}$ NMR (Pyridine- $\left.d_{5}, 400 \mathrm{MHz}, \delta \mathrm{ppm}\right) \delta$ : $1.93(1 \mathrm{H}$, $\mathrm{H}-1 \alpha), 2.24$ (1H, H-1 $\beta$ ), 4.13 (1H, d, $J=12.86, \mathrm{H}-2), 4.22$

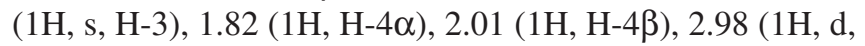
$J=12.86, \mathrm{H}-5), 6.27$ (1H, s, H-7), 3.58 (1H, m, H-9), 1.75

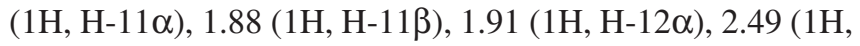

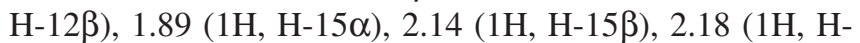
$16 \alpha), 2.62$ (1H, H-16ß), 3.14 (1H, H-17), 1.22 (3H, s, H-18 
Me), 0.99 (3H, s, H-19 Me), 1.02 (3H, s, H-21 Me), 3.94 (1H,

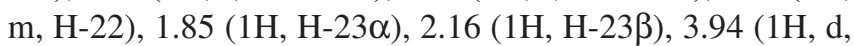
$J=3.99$, H-24), 1.75 (1H, H-25), 1.01 (3H, s, H-27). ${ }^{13} \mathrm{C}$ NMR spectral data Table-1.

Antibacterial activity: It was reported by Islam and his co-workers ${ }^{5}$ and others ${ }^{7}$ that the extract from Sida rhombifolia has antibacterial effects, so we tested antibacterial activity of those compounds on Bacillus subtlis, Staphylococcus aureus and Escherichia coli with a concentration of $20 \mathrm{mg} / \mathrm{mL}$, using disk diffusion method. It is shown that compound $\mathbf{1}$ has inhibitory effect on Escherichia coli. The results were shown in Table-2.

\begin{tabular}{cccccc}
\multicolumn{7}{c}{ TABLE-1 } \\
\hline Carbon & $\delta_{\mathrm{C}}$ & Carbon & $\delta_{\mathrm{C}}$ & Carbon & $\delta_{\mathrm{C}}$ \\
\hline C-1 & $36.23(\mathrm{t})$ & C-10 & $38.73(\mathrm{~s})$ & C-19 & $24.51(\mathrm{q})$ \\
C-2 & $68.20(\mathrm{~d})$ & C-11 & $21.12(\mathrm{t})$ & C-20 & $78.18(\mathrm{~s})$ \\
C-3 & $68.11(\mathrm{~d})$ & C-12 & $31.76(\mathrm{t})$ & C-21 & $66.00(\mathrm{q})$ \\
C-4 & $32.53(\mathrm{t})$ & C-13 & $47.97(\mathrm{~s})$ & C-22 & $78.18(\mathrm{~d})$ \\
C-5 & $51.44(\mathrm{~d})$ & C-14 & $84.27(\mathrm{~s})$ & C-23 & $37.98(\mathrm{t})$ \\
C-6 & $203.73(\mathrm{~s})$ & C-15 & $31.37(\mathrm{t})$ & C-24 & $77.17(\mathrm{~d})$ \\
C-7 & $121.82(\mathrm{~d})$ & C-16 & $21.71(\mathrm{t})$ & C-25 & $33.89(\mathrm{~d})$ \\
C-8 & $166.27(\mathrm{~s})$ & C-17 & $47.56(\mathrm{~d})$ & C-26 & $17.11(\mathrm{t})$ \\
C-9 & $34.44(\mathrm{~d})$ & C-18 & $18.05(\mathrm{q})$ & C-27 & $19.68(\mathrm{q})$ \\
\hline
\end{tabular}

\begin{tabular}{|c|c|c|c|}
\hline \multicolumn{4}{|c|}{$\begin{array}{c}\text { TABLE-2 } \\
\text { ANTIBACTERIAL ACTIVITY OF THOSE COMPOUNDS } \\
\text { FROM Sida szechuensis (ALL THE COMPOUNDS } \\
\text { WERE TESTED AT } 20 \mathrm{mg} / \mathrm{mL} \text { CONCENTRATION) }\end{array}$} \\
\hline \multirow{2}{*}{ No. of compound } & \multicolumn{3}{|c|}{ Test organisms and zone of inhibition (mm) } \\
\hline & E. coli & S. aureus & B. subtlis \\
\hline 1 & $11.4 \pm 1.0$ & - & - \\
\hline 2 & $8.7 \pm 0.5$ & - & - \\
\hline 3 & - & - & - \\
\hline 4 & $7.0 \pm 0.6$ & - & - \\
\hline 5 & - & - & - \\
\hline 6 & - & $7.0 \pm 0.7$ & - \\
\hline 7 & - & - & - \\
\hline 8 & $6.0 \pm 1.0$ & - & $6.7 \pm 0.4$ \\
\hline 9 & - & - & - \\
\hline 10 & - & - & - \\
\hline 11 & - & - & - \\
\hline Penicillin & $9.3 \pm 1.4$ & $9.5 \pm 0.5$ & $6.5 \pm 0.5$ \\
\hline
\end{tabular}

Compound 1 (Fig. 1) was obtained as colorless crystal. Its molecular formula was assigned as $\mathrm{C}_{27} \mathrm{H}_{44} \mathrm{O}_{8}$ on the basis of positive ion HRFABMS $\left(\left[\mathrm{M}^{+}\right], m / z 496.3035\right)$ and ${ }^{13} \mathrm{C}$ DEPT spectrum. The sterol-like structure of compound $\mathbf{1}$ was clearly indicated by the NMR spectrum. The ${ }^{1} \mathrm{H}$ NMR showed two tertiary methyl groups resonating in the high field region, reminiscent of the angular methyl of a sterane and the ${ }^{13} \mathrm{C}$ NMR spectrum confirmed presence of one oxygen-linked tetrasubstituted carbon atoms which indicated the presence in the molecule of one ketone ( $\delta 203.73)$, as well as a trisubstituted

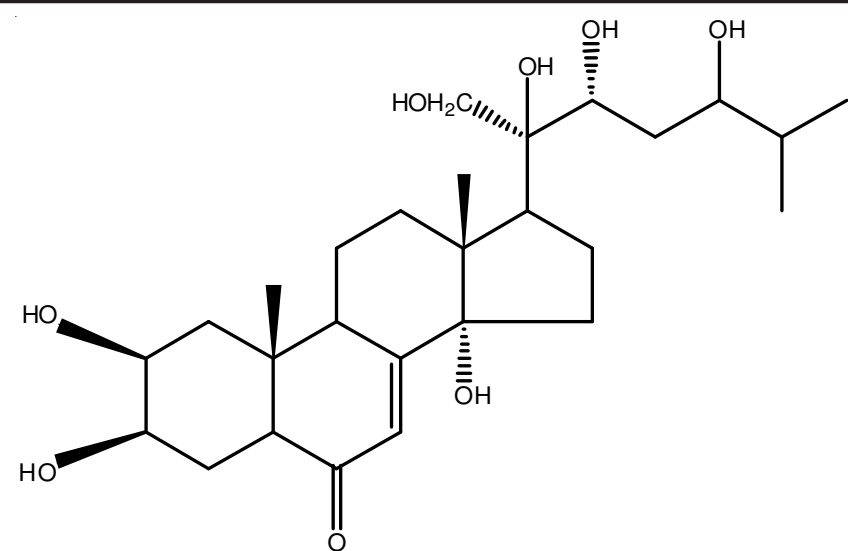

Fig. 1. Structure of compound $\mathbf{1}$

double bond [ $\delta 121.82(\mathrm{C}-7)$ and $\delta 166.27$ (C-8)], conjugated with one of the carbonyl groups as shown by the very deshielded ${ }^{13} \mathrm{C}$ chemical shift of the $\beta$-olefine quaternary carbons and by UV absorption at $\lambda_{\max }=243 \mathrm{~nm}$, together with two oxy-methine groups $[\delta 68.20(\mathrm{C}-2)$ and $\delta 68.10(\mathrm{C}-3)]$. All of these above data were in good agreement with the structural features of an ecdysteroid-type nucleus. And a $2 \mathrm{H}$ singlet at 4.36 were reasonably attributable to an oxymethylene of a saturated side chain hydroxylated at C-20. Two methyl doublets at $\delta 0.99$ and $\delta 1.01$, characteristic of methyl of 26 and 27, respectively. In addition, the ${ }^{13} \mathrm{C}$ NMR spectrum also confirmed presence of a oxymethylene $[\delta 66(\mathrm{C}-21)]$ and another two oxymethine groups $[\delta 78.18(\mathrm{C}-22)$ and $\delta 77.17(\mathrm{C}-24)]$. And compare with known compounds ${ }^{8-10}$, this compound was shown to be $2 \beta, 3 \beta, 14 \alpha, 20,22 \mathrm{R}, 24$-heptahyd-roxycholest-7-en-6-one.

In conclusion, present results have shown that compound 1 from Sida szechuensis possess antibacterial activity. Further comprehensive pharmacological investigations are needed to elucidate the exact mechanism of the antimicrobial effect of Sida szechuensis. All the compounds were tested at $20 \mathrm{mg} / \mathrm{mL}$ concentration.

\section{REFERENCES}

1. D.J. Du, X.F. Shi, C.Q. Ran, Z.J. Wen, L.L. Peng and D.C. Xie, Chin. Tradit. Herbal Drugs, 26, 594 (1995).

2. X. Chen, D.J. Du, N.N. Fang et al., Chin. Tradit. Herbal Drugs, 27, 63 (1996).

3. C.S. Yao and Y.L. Xu, Acta Botanica Yunnanica, 22, 503 (2000).

4. N. Kawabata and M. Nishiguchi, Appl. Environ. Microbiol., 54, 2532 (1988).

5. M. Ekramul Islam, M. Ekramul Haque and M.A. Mosaddik, Phytother. Res., 17, 973 (2003).

6. S. Venkatesh, Y.S. Rami Reddy, B. Suresh, B.M. Reddy and M. Ramesh, J. Ethnopharmacol., 67, 229 (1999).

7. V. Ravi Kanth and P.V. Diwan, Phytother. Res., 13, 75 (1999).

8. V. Costantino, C. Dell'Aversano, E. Fattorusso and A. Mangoni, Steroids, 65, 138 (2000).

9. K. Vokác, M. Budesnský, J. Harmatha and J. Kohoutova, Phyotochemistry, 49, 2109 (1998)

10. B.M.R. Bandara, L. Jayasinghe, V. Karunaratne, G.P. Wannigama, M. Bokel, W. Kraus and S. Sotheeswaran, Phytochemistry, 28, 1073 (1989). 